\title{
JAMES BLAIR (1747-1817), PROVINCIAL DENTIST
}

\author{
by
}

\section{CHRISTINE HILLAM*}

THE LATE eighteenth and early nineteenth centuries saw a considerable increase in the number of dentists, as barbers, hairdressers, perfumers, jewellers and other traders extended their field of operation and declared themselves capable of curing all dental ills, usually painlessly and undetectably. Their more flamboyant side made them the butt of the contemporary caricaturists.

There have been studies of a number of London and Edinburgh practitioners of the period, concerned primarily with those who were notable for their scientific contributions to dentistry or for their sheer personal eccentricities, but little detailed work has been done on the ordinary provincial dentist. Such a man was James Blair. By means of a detailed examination of his life, this paper aims to give some preliminary answers to the following questions: what sort of men took up dentistry? What was their social and commercial background? How much time did they devote to dental practice? What kind of treatments did they have to offer the public? However, only further work on the period will reveal how typical Blair was of his kind.

\section{EARLY LIFE}

James Blair was born in 1747 in Blairgowrie, Perthshire, the son of James Blair, a shoemaker and officer of the kirk. His mother was Margaret Barrta. ${ }^{1}$

In the eighteenth century, Blairgowrie was even smaller than it is now, having a population of only 500 in $1790^{2}$ compared with 5,554 in 1971 . At the beginning of the nineteenth century it became one of the centres of the flax industry ${ }^{3}$ and a number of mills were built along the river Ericht running between Blairgowrie and Rattray. Craig Mill, belonging to the Saunders family (relatives by marriage to the Blairs) dates from this period. However, at the earlier date of about 1760 when James Blair must have been ready to take up a trade, there were presumably fewer openings for enterprising young men who were not content with village life. There are a number of entries for "Blairgowrie" in the contemporary lists of Edinburgh apprentices" and it would seem not unreasonable to suppose that boys also left the community for other destinations.

James Blair may have begun his mobile career by going to Edinburgh to work for

*Christine Hillam, B.A., Dental History Unit, Department of Oral Pathology, University of Birmingham Dental School, St. Chad's Queensway, Birmingham B4 6NN. Present address: 6 Brancote Road, Birkenhead.

1 Blairgowrie Old Parochial Register, New Register House, Edinburgh.

- Personal communication from D. Moody, Librarian, Blairgowrie.

- J. A. R. MacDonald, History of Blairgowrie, Blairgowrie, 1899.

- Marguerite Wood (ed.), Register of Edinburgh apprentices, 1756-1800, Scottish Record Society, vol. 92, 1963. 
Gilbert Blair, a barber in St. Mary's Wynd. Gilbert Blair had been a Burgess of Edinburgh since $1743^{5}$ and had connexions of some kind with Blairgowrie in that one of his first apprentices was Thomas Blair, son of Peter Blair, a shoemaker in the village in $1748 .^{\circ}$

A boy would normally be apprenticed to such a trade at fourteen. However, James Blair's four-year apprenticeship was registered as beginning on 22 October 1778.4 As Blair would have been thirty-one at the beginning of this arrangement, it would seem that if he actually served an apprenticeship to Gilbert Blair as a boy, it was not formally registered at the time. At this period in Edinburgh registration was not as systematic as it might have been. Some apprenticeships were not registered at all, whilst others were registered well after the event. ${ }^{7}$ On balance, the evidence suggests that James had indeed worked for Gilbert Blair, and was probably apprenticed to him.

It is certain that James and Gilbert Blair were related in some way, ${ }^{8}$ although the brevity of the entries in the Blairgowrie Old Parochial Registers and the omnipresence of Blairs in the parish make it difficult to establish the precise connexion. James and his descendants kept in active contact with Gilbert's son, Robert, a Church of England cleric who was to stand godfather for two of James's grandchildren.10

By the end of the 1760s James appears to have been seized by the restlessness which characterized his life and he left Edinburgh for London. Here, he says, he worked for a Mr. Ritchie, of Rupert Street, like Gilbert Blair, a barber and hairdresser. However, even the glamour of the fashionable clientele and the attractions of the metropolis palled after a while and he joined Mr. Miller's Company of

'Charles B. Boog Watson (ed.), Roll of Edinburgh burgesses and guild brethren, 1701-1760, Scottish Record Society, vol. 62, 1930.

- Charles B. Boog Watson (ed.), Register of Edinburgh apprentices, 1701-1755, Scottish Record Society, vol. 61, 1929.

' Personal communication from W. M. Makey, City Archivist, Edinburgh.

8 Will of Robert Blair, D.D. Prerogative Court of Canterbury. PRO 11/1889 RH22-RH24.

- Robert Blair, 1759-1837. This remarkable gentleman was born in 1759 in Edinburgh. He was educated at Heriot's Hospital and Edinburgh High, going on to Edinburgh University in 1775-1776 and for a further period from 1778-1779. Thirteen years later, at the exceptional age of thirty-two, he was admitted sizar at Pembroke College, Cambridge, and in the same year (1792) entered into the living of Barton St. Andrews in the diocese of Norwich, remaining Rector there until his death in 1837. He styled himself "Robert Blair, DD" although where he obtained his doctorate has not been discovered. His will speaks of his having spent some time at the Court of Naples, presumably between 1779 and 1792, and Venn consequently assumes his degree was a foreign one. Robert Blair's will shows him to have been a man of some wealth. His bequests in money and securities alone total nearly $£ 8,000$, no mean sum for 1838 . The largest single amounts were left to James Blair's granddaughter, Charlotte Wortley, who was living with him in Euston Square at the time of his death. The fact that her mother is described as a "paternal relative" puts the existence of a relationship between these two branches of the Blair family beyond doubt. Other of James's grand-children are named as legatees, together with the Bishop of Norwich, Robert's successor at Barton St. Andrews, the Moderator of the Church of Scotland, the Principal of the College of Edinburgh, and the major Edinburgh Schools of the time. To these official bodies he left a total of $£ 3,500$ to establish charities and bursaries. His extensive library (which included a number of books presented to him by duchesses during his stays at the courts of Sicily and Naples) were divided among the academic establishments of Edinburgh. To the Library at Linlithgow, founded by his maternal uncle, George Henry, the author of a large 'History', he left the books his uncle had given him when he first went to university.

${ }_{10}$ Manuscript list of the children of Nathaniel William Wortley and Charlotte Blair; possession of Mrs. P. Molyneux. 


\section{Christine Hillam}

Comedians, touring the country as their resident "dresser" and playing the occasional part in a play when the need arose. 11

In March 1769 the company arrived in Leicester for a four-months' stay. They opened the season on 6 March with a piece entitled "The Earl of Essex", Blair taking the part of an officer. ${ }^{12}$ There followed in quick succession other items from their repertoire: "Tancred and Sigismunda" on 13 March and "The Wonder" on 27 March when Blair was called on to play Vasquez. ${ }^{13}$ Perhaps it was a comment on his performances in these two plays that when "Midas" was presented on 17 April, Blair was relegated to "Sleeping Shepherd". He had no part at all in "The Provoked Husband" and "A Journey to London", performed on 24 April. At the same time he would appear to have been practising as a hairdresser in the town: ${ }^{11}$

One cannot say whether Blair was somewhat disenchanted by now with the life of the travelling company of actors or whether he was overwhelmed with the charms of eighteenth-century Leicester, but whatever the reason, at the age of twenty-two, he placed the following notice in the Leicester and Nottingham Journal for 24 June 1769:

James Blair

Hairdresser, Perruke and Tète-Maker, from Mr. Richie's, in Rupert-street, London (but last Dresser to Mr. Miller's Company of Comedians) Begs leave to return his most grateful Thanks for the many Favours conferr'd on him by the Ladies and Gentlemen of this Town and County. And as many of his Friends have honoured him with an intimation of their future Favours if he would quit the business of the Company and live at Leicester: In Compliance with their Request, he takes this opportunity of informing them, and the Public in General, that he still remains at his Appartments (which are for the present) at the Griffin, in the High-street, where he flatters himself he shall receive their Countenance and Protection, assuring them it shall be his Constant Endeavour to Merit the Honour of their Employ, by Dressing Ladies and Gentlemen in the newest Fashions; as also by making Ladies' Tètes and Gentlemen's Curls and Locks, together with Bag and other Wigs, many Patterns of which he always keeps by him. As also Black Pins, Pomatoms, Orange-Butters, Jessamine Butter, Powders plain and scented, Combs and every other Article of the Business, which he sells at the most reasonable Rates.

Thus ran the first of a series of elegant, if rather verbose, advertisements which were to appear in local newspapers in different parts of the country until his death in 1817.

When Blair decided to settle there, Leicester was still a fairly small county town; the population in 1730 has been put at about 8,000,14 the present size of Ashby-dela-Zouch or Minehead. There was no paving or lighting in the main streets for the first few years that Blair lived there.

There are no surviving trade directories for Leicester for this period, but if advertisements in the Leicester and Nottingham Journal can be taken as representing the true situation he must have encountered little opposition from already established hairdressers and peruke-makers. One might have expected a flood of advertisements from anxious. Leicester tradesmen following the arrival of this fashionable young man from London, but no such reaction materialized. He was able to set up business

${ }^{11}$ Leicester and Nottingham Journal (hereinafter referred to as LNJ), 24 June 1769.

12 LNJ 4 March 1769.

18 LNJ 18 March 1769.

16 R. A. McKinley (ed.), A History of the County of Leicester, London, Oxford University Press, vol. 4, 1958. 


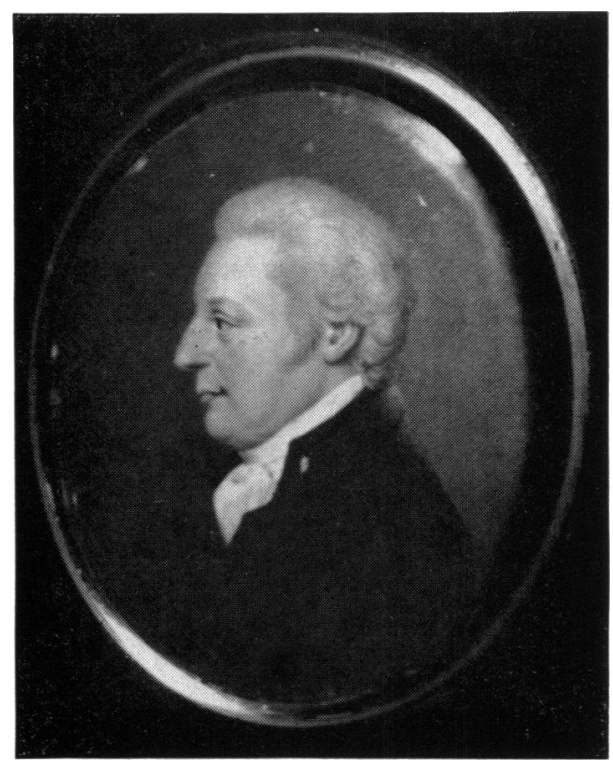

Figure 1

James Blair (1747-1817). Reproduced by kind permission of Mrs. P. Molyneux. 


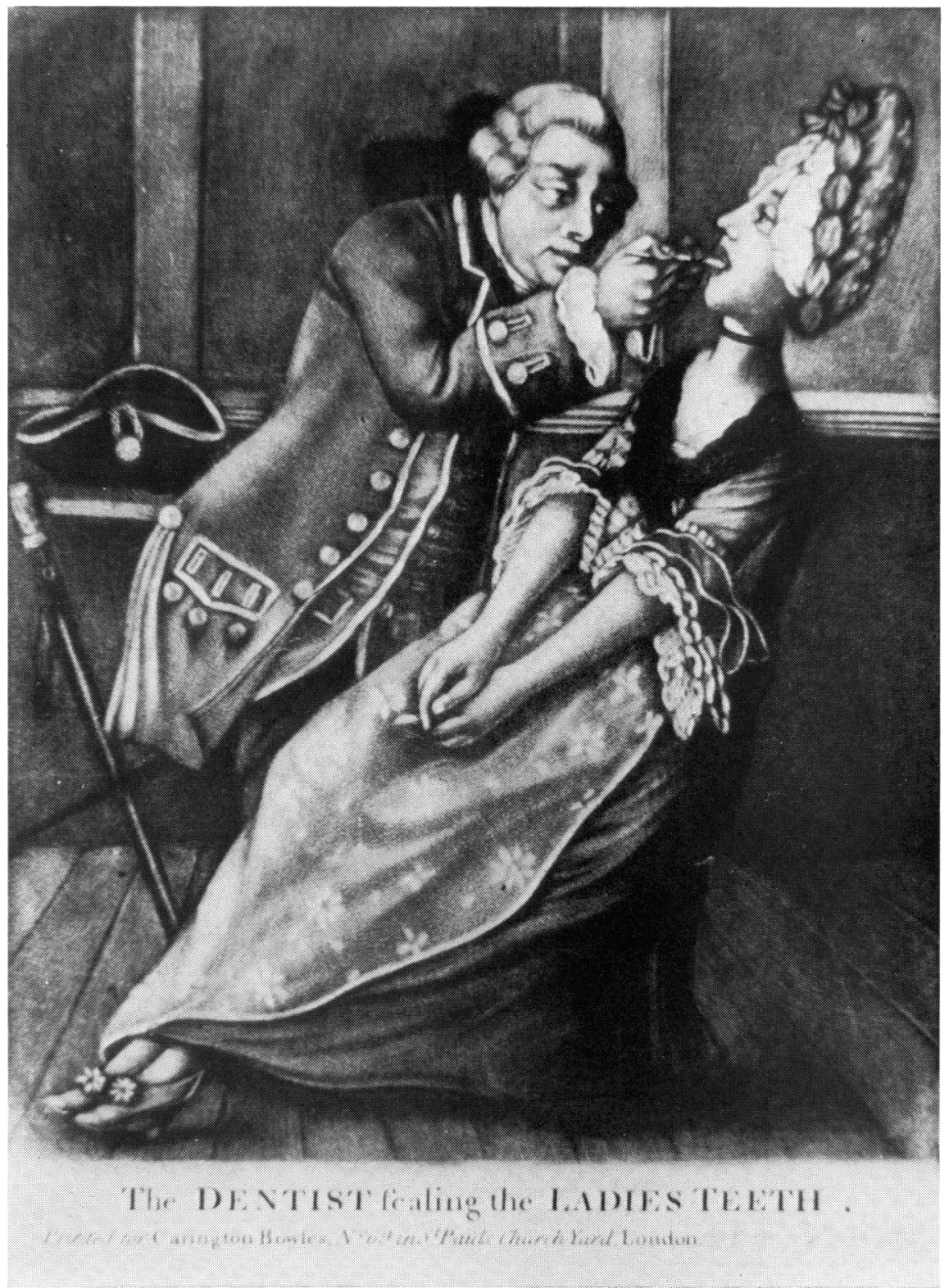

Figure 2

"The dentist scaling the ladies teeth". Mezzotint, hand coloured, c. 1770, printed for Carrington Bowles. R. A. Cohen Collection. 


\section{James Blair (1747-1817), provincial dentist}

with ease in Leicester where the trading monopoly had been broken in 1749 when the town was prosecuted by a non-freeman trader and the old régime virtually collapsed. ${ }^{15}$ Blair never became a freeman of Leicester and hence none of his apprentices appears in the Borough Records.

\section{PERUKE-MAKER, HAIRDRESSER, PERFUMER AND TOYMAN, 1771-1787}

Still living at the "Griffin", Blair advertised for an apprentice in December 1769.18 One imagines he was able to rent rooms at the inn from which to trade. In fact not until August 1771 did he leave the "Griffin" to set up business, at the age of only twenty-four, in his own shop in the Coal Hill, Belgrave Gate. ${ }^{17}$

Now he extended his activities. As well as dressing "Ladies' and Gentlemen's Hair in the newest and most prevailing Fashions", "Ladies and Gentlemen may be likewise furnished with all sorts of perfumery; and those who have thin hair inclining to fall off, may be furnished with a pomatum, which will not only fix the roots of it, but strengthen, nourish and increase the growth." This is the first indication of an interest in matters therapeutic but there is still no mention of dentistry or even of the sale of tooth-powder.

Much of his business would seem to have been done in clients' homes as he undertook to wait upon patrons "either in Town or Country, on the shortest notice." Again he was seeking an apprentice. Certainly trade must have been good by May $1772^{18}$ when a further announcement declared: "Wanted immediately: A Journeyman Perruke-Maker and Hairdresser, who can have a good Character; such a one may have constant Employ and good Wages, by applying to J. Blair, Hair-dresser in Belgrave-gate, Leicester."

The next two years appear to have been spent in developing the business since 1775 saw him able to raise capital to move yet again, ${ }^{19}$ this time to Gallowtree Gate, near the "Crane's Inn", where he stayed for twenty-five years. So extensive were his new premises that he had "Two dining rooms and 2 lodging rooms .... . to LETT, ready furnished, likewise good Warehouses." As well as extending his business interests by renting off rooms, he was also able to widen the range of his stock to include such items as "pinching Toupee French and creaping [sic] irons, scissors, razors, ... penknives . . . Goulde's best rappee snuff." He had, he said, "laid in a choice assortment of Perfumery and Cutlery goods from the best makers." His staple continued to be a wide variety of hair-powders of different colours and perfumes ("grey, brown, pink, marachal and violet"), pins, swan's-down puffs, powder machines and "all sorts of wash balls", but for the first time he advertised "every sort of shaving and Teeth brushes." By now he was obviously not only a perukemaker and a hairdresser, but also a perfumer and toyman.20

One month before moving into his new shop, James Blair married, on 12 February,

16 Henry Hartopp (ed.), Register of the Freemen of Leicester, 1196-1770, Leicester, 1927.

16 LNJ 30 December 1769.

17 LNJ 24 August 1771.

10 LNJ 9 May 1772.

10 LNJ 4 March 1775.

- A manufacturer and/or seller of small items or trinkets in metal or ivory. 


\section{Christine Hillam}

Charlotte Jordan, the daughter of a Leicester surgeon, Samuel Jordan. ${ }^{21}$ In November they produced their first child, James. Their second son, Samuel Jordan Blair, was born on 10 July 1777 and two daughters, Charlotte and Jane, in 1779 and 1780 respectively. 22

Apart from a further advertisement for an apprentice peruke-maker and hairdresser on 15 February 1777 (in which he also states that he sells Mrs. Bernard's Tincture for the teeth) ${ }^{23}$ and another similar one on 4 March 1786, Blair's name scarcely figures in the local press for the rest of this period. One of Blair's former apprentices, William Davis, set up his own business in $1786,{ }^{24}$ and so one imagines there was no shortage of demand for the hairdressing trade in the town. Blair's only direct contact with dentistry would appear to have been the occasion on which a practitioner named Restieaux from Norwich used his premises during his 1785 visit to Leicester. ${ }^{25}$

Some insight into Blair's possible income is given by Mr. Ball, a hairdresser new to Leicester, who, in an attempt to undercut his competitors, advertised in the Leicester and Nottingham Journal on 6 March 1779. Apparently he sold tètes with two curls at $8 \mathrm{~s}$., whilst their usual price was $12 \mathrm{~s}$. His cushions were priced at $2 \mathrm{~s}$. instead of $3 \mathrm{~s}$. "Very large curls" could be had for 2s. 6d. the pair. Carl Moritz, writing in 1782, states that he had to pay a hairdresser a shilling to shave him and put his hair in order. ${ }^{26}$ This was at a time when meat was fetching $4 d$. to $5 d$. a pound, butter $8 d$. and bread 1s. $6 d$. the quartern loaf. ${ }^{27}$ Burnett also tells us that the cost of a wig in the late eighteenth century was anything from $£ 5$ to $£ 20 .{ }^{28}$ The common wage for an agricultural labourer of the 1770 s he puts at about $7 s .{ }^{29}$ and considers that an income of $£ 50-£ 100$ a year represented a fair trade for a provincial shopkeeper. ${ }^{30}$

Blair's settled condition must have received something of a jolt in 1781 when his wife Charlotte died in July. Left a widower with one son, James (Samuel Jordan had already died), and two daughters, Charlotte and Jane, Blair was presumably faced with reappraising the course he wished his life to follow. On 14 April of the next year his eighteen-month-old daughter Jane died, ${ }^{21}$ to be buried in the same grave in St. Martin's churchyard as her mother and brother.

In 1782 Gilbert Blair ceased to be listed in the Edinburgh directories and it would seem that James contemplated leaving Leicester and returning to Scotland to carry on Gilbert's business. To have set up in Edinburgh he would have needed to be a burgess of the city, for which one of the qualifications was having served an apprenticeship to another burgess. Blair must then have found that his apprenticeship had not

21 Register of marriages, St. Martin's parish, Leicester. Leicester Record Office.

22 Register of baptisms, St. Martin's parish, Leicester. Leicester Record Office.

23 LNJ 15 February 1777.

2 LNJ 25 November 1786.

26 LNJ 27 August 1785.

20 Carl Philip Moritz, Journeys of a German in England in 1782, trans. and ed. by Reginald Nettell, London, Jonathan Cape, 1965, p. 120.

27 John Burnett, $A$ history of the cost of living, Harmondsworth, Penguin Books, 1969, p. 136.

2 Ibid., p. 145.

20 Ibid., p. 164.

${ }^{20}$ Ibid., p. 172.

"1 Register of burials, St. Martin's parish, Leicester. Leicester Record Office. 


\section{James Blair (1747-1817), provincial dentist}

been registered and set about rectifying this omission. His indentures were registered as taking effect from 22 October 1778 and he became a burgess of Edinburgh on 5 December $1782 .{ }^{32}$ It seems highly unlikely that the entries in the Rolls can be taken at their face value, since, as has been pointed out earlier, Blair was thirty-one in $\mathbf{1 7 7 8}$ and two of his children were baptised in Leicester during the four years when he was supposed to be bound to Gilbert Blair.

However, this possible plan to move to Edinburgh came to nothing. Like most eighteenth-century widowers he quickly remarried. His second wife (the marriage took place on 25 July 1782) was Martha Hodgkin (1756-1829). She came from Market Overton in Rutland, not far from Woolsthorpe, the home of the Newton family. Although the claim was not supported with any firm proof, her descendants considered Martha to be some kind of cousin to Sir Isaac Newton (1642-1727). ${ }^{33}$ The daughter of Greer and Ann Hodgkin, she may have been a descendant of Newton's mother's second marriage to the Rev. Barnabas Smith, Rector of North Witham. ${ }^{34}$

The following year, 1783, saw the birth of their first child, Greer Hodskin [sic], destined like most of their other children to die early. Of the five children born to them between 1785 and 1794 (Orlando, 1785; William, 1786; Martha, 1788; Jane, 1793; Gilbert, 1794) only two, Martha and Jane, survived childhood. One suspects that, given an obvious high fertility with children born in rapid succession, there may also have been a number of miscarriages or stillbirths between 1789 and 1792 . Had there been other live births the children would presumably have been baptised at St. Martin's church, Leicester, since Blair's continuing presence at Gallowtree Gate is confirmed by his appearance in newspaper advertisements and trade directories.

\section{DENTISTRY IN LEICESTER, 1769-1787}

It is interesting to speculate as to whether Blair became at all involved with the tooth-pulling side of the surgical practice of his first father-in-law, Samuel Jordan. Certainly very few self-declared dentists saw fit to advertise in the Leicester and Nottingham Journal. Between Blair's arrival in the town in 1769 and his removal to the new shop in Gallowtree Gate in 1775, the only visiting dentist noted in the newspaper had been Samuel Crawcour, "dentist and operator for the teeth and gums". Formerly of Hanover, he stated that he was now living in Gloucester. He was able to make teeth as white as alabaster without harming the enamel and could fasten loose teeth merely by clearing the gums of scurvy and the teeth of scales of various colours. Whether painlessly removing stumps or filling rotten teeth, no operation took more than twenty minutes. He was prepared to "forfeit ten times the sum of money [charged] if his operation and his advertisement shall not prove alike". ${ }^{25}$ Presumably he was one of the family of "notorious empirics of Polish extraction" referred to by Campbell..$^{30}$

32 Charles B. Boog Watson (ed.), Roll of Edimburgh burgesses and guild brethren, 1761-1841 Scottish Record Society, vol. 68, 1933.

s Information written on the reverse of a portrait of her daughter, Jane Robertson; possession of Mrs. P. Molyneux.

34 Dictionary of national biography. $\quad{ }^{26}$ LNJ 18 February 1775.

36 J. Menzies Campbell, Dentistry then and now, Glasgow [privately printed], 1963, p. 265. 


\section{Christine Hillam}

Neither of the dentists who are known to have visited Birmingham during the same period (Lewis from Oxford ${ }^{37}$ and Grimaldi from London) ${ }^{38}$ appears to have included Leicester on his itinerary. One can only assume that most of the tooth-pulling in the town was carried out by the surgeons, apothecaries, travelling tooth-drawers on market days, and perhaps by the barbers and hairdressers. In 1783 a Northampton surgeon and apothecary was advertising for an apprentice who was to be "allowed profits of bleeding and toothdrawing done in shop". As late as 1882 it could be said "Hairdressers, perfumers, jewellers, blacksmiths and others, have hitherto exercised the function of toothdrawing". ${ }^{40}$ Even a town the size of Birmingham could not boast a resident actually calling himself "dentist" in the trade directories of the 1770s, although there were one or two tooth-drawers."1

However, from 1775 Leicester began to attract the attention of more itinerants. Mrs. Bernard passed through in December 1776, leaving behind her supplies of her patent "liquid" in one-guinea, half-guinea and quarter-guinea bottles, the sole agents in Leicester being Gamble, the grocer, and James Blair, hairdresser. (The price of the liquid must have been extremely high when one bears in mind that the average price of most patent medicines in Bath in the eighteenth century was between one and three shillings.) $)^{12}$ Like Crawcour in early 1775 , she claimed that, applied three times a week, her product would render the teeth "white as alabaster" although she did not guarantee that it would not harm the enamel in the process. (This was only a few years after Thomas Berdmore, the famous London dentist who held a royal appointment, had shown that the tooth preparations then in current use could destroy the enamel in an alarmingly short time.) $)^{\text {ts }}$ It is interesting that when Blair himself advertised the "liquid" he made no claims for it and appeared not to stock the guinea size. ${ }^{23}$

Crawcour paid a return visit to Leicester in June 1779, establishing markets for his products whilst he was in the town." The following year, Mr. Moor from Oxford included Leicester on his itinerary, staying at Mr. Kettleby's in the Market Place for fourteen days. He returned to the same premises in August of 1781..$^{45}$

As stated earlier, James Blair himself was host to an itinerant dentist in August 1785. Mr. Restieaux claimed to be a surgeon-dentist from Norwich, and "late from Nottingham" where it emerges he had just spent twelve days. ${ }^{46}$ One wonders at the

\footnotetext{
"Aris's Birmingham Gazette (hereinafter referred to as ABG) 16 September 1771.

" ABG 28 June 1773.

* ABG 1 December 1783.

- Quoted by John Tomes, 'On the proceedings of the last four years', Br. J. dent. Sci., 1882, 25: 881-889.

"1 William Nailer in Sketchley's Universal directory . . . of Birmingham, 1770, and Swinney's New Birmingham directory, 1774 and 1775; Edward Withanall in Sketchley's 1770 directory.

¿2 P. S. Brown, 'Medicines advertised in eighteenth-century Bath newspapers', Med. Hist., 1976, 20: $152-168$.

13 Thomas Berdmore, A treatise on the disorders and deformities of the teeth and gums, London, 1768, p. 228.

« LNJ 26 June 1779.

$\omega$ LNJ 4 August 1781.

- Cresswell and Burbage's Nottingham Journal, 14 May 1785.
} 


\section{James Blair (1747-1817), provincial dentist}

quality of treatment he provided since he never ventures to advertise again in Leicester after this one visit. Like his contemporaries he cleaned, scaled and filled the teeth and inserted "Real, or Artificial Teeth, or a whole Set, without the Pain of drawing the Stump." He carried credential letters from "the most eminent Physicians and Surgeons at Norwich" where he had lived for nine years. ${ }^{25}$ This would suggest that this was his first visit to the town.

Mr. Crawcour (now of Short Street, Moorfields, London) was once more passing through the area in January 1786, visiting Market Harborough and staying at the "Dolphin" there until early March."7 Mr. Jeffs arrived in Leicester, via Manchester, on 18 November of the same year, stating that he had just come over from Ireland. He took temporary appartments at Mr. Chester's, near Cole-hill in Belgrave Road. He claimed, on a later visit, ${ }^{48}$ that he had been visiting Leicester for seven to eight years, but 1786 appears to have been the first time he placed an advertisement in the Leicester and Nottingham Journal. He would seem to have been an eighteenth-century dentist with nothing to fear from a return visit and he was back in the town in February of 1787. Other dental visitors a few weeks earlier had been the Sedmons, who claimed to have been in Edinburgh for some time before their most recent abode, Berlin."10

At the same time there appears to have been an increased demand for dentifrices, tooth-powders and tinctures. However, the advertisements have to be treated with caution as the main Leicester agent for most of them was Gregory, the printer of the paper, who, as frequently happened, inserted notices for the patent medicine he sold when this aspect of his trade was slipping or when there was too little paid advertising copy that week to fill the paper. "Hemet's Essence of Pearl" and his "Pearl Dentifrice" are undoubtedly the most frequently advertised in the 1770s. In 1772 they appeared in eight issues between March and July. Itinerant dentists also did their best to sell their own products through agents when their visit was over, as did Mrs. Bernard, Crawcour, and Moor. There is also the occasional advertisement for a London-made product, such as "Hamilton's Tincture for the Tooth-ache and Head-ache", advertised in 1777.50 Dr. Johnson, "Practitioner in Physic and Surgery", was selling his "Golden Essence for the Tooth-ache" at 1s. a bottle while staying at Mr. Webster's the glazier's." Jackson's "True British Powder for the Teeth" only put in three appearances, one in November 1779, ${ }^{52}$ the second in December 1779, one on 4 March 1780. Even Swinfen, a Leicester surgeon, advertised his own toothpowder in 1780 . 4

\section{JAMES BLAIR, DENTIST AND POLYTECHNICIAN, 1787-1800}

As has been seen, visiting dentists were beginning to take an interest in Leicester in the late 1770s and the 1780s. This may have been the spur which prompted James

"7 LNJ 28 January 1786.

68 Leicester Journal (hereinafter referred to as LJ) 2 February 1788.

a LJ 3 February 1787.

s. LNJ 26 July 1777.

11 LNJ 23 January 1779.

12 LNJ 20 November 1779.

* LNJ 18 December 1779.

4 LNJ 1 April 1780. 


\section{Christine Hillam}

Blair and his fellow hairdresser, Clay Hextall, to assert their interest in the trade before it became the province of outsiders. On 7 July 1787 both of them advertised in the Leicester Journal. Hextall, however, soon seems to have disappeared from the scene as an advertising dentist. Blair's advertisement read as follows:

\section{Blair, Dentist}

Leicester

Begs leave to inform the public, that he removes the tartar from the teeth, fastens them if loose, and brings the gums to a proper colour and hardness: he likewise makes artificial Teeth, fixes them without pain, and in such a manner as not to be distinguished from natural ones. He has likewise prepared a Tincture and Dentifrice which are much approved and may be had at his shop in Gallowtree-gate where the following articles are also sold

Ruspini's Tincture and Dentifricess

Ruspini's Styptic

Hemet's Essence of Pearl and Pearl Dentifricese

ss Bartholemew Ruspini has been exhaustively examined by a number of dental historians, notably J. Menzies Campbell, from whose Dentistry then and now, op. cit., note 36 above, the following information is taken: Ruspini was born near Bergamo in 1728. After training as a surgeon he decided to specialize in dentistry and went to Paris. Shortly afterwards, in 1759, he arrived in Bath for the season, and subsequently visited many of the major towns in the country. He settled in London in 1766, practising from 32 St. Alban's Street, opposite Carlton House and not far from Richie's the hairdresser's where Blair appears to have been working in the 1760s. Ruspini's Treatise on the teeth was produced in 1768.

He had considerable standing in society, unlike many of his fellow-tradesmen. In 1800 he was appointed Surgeon-Dentist to the Prince of Wales and the Duke of Sussex. A prominent mason, he was instrumental in founding the Royal Cumberland Freemason School for orphan girls in 1788. The following year he was made a "Chevalier" by Francis, Duke Sfortia.

His tincture, dentifrice and styptic were widely sold. In 1783 he was charged with contravening the new Medicines Stamp Act by selling them without stamps as he should have done, not being a regular member of the medical profession.

He was the subject of a number of portraits and caricatures, the most famous of which is probably the Rowlandson cartoon 'Transplanting of teeth' (1787).

Ruspini's tooth-powder was said to be composed of powdered orris root, Armenian bole, powdered crab's eyes, pimento powder, and rose pink, all mixed together with great care. It was sold in containers bearing his coat-of-arms and accompanied, as Blair indicates by a copy of his Treatise. The tincture was composed of rectified spirit of wine, essence of scurvy grass, distilled water, powdered orris root, cloves, ambergris, alum, and sage. Ruspini's styptic was launched on the market in 1785 with a pamphlet entitled $A$ concise relation of the effects of an extraordinary styptic. It achieved some fame when used successfully to stem a haemorrhage in the Prince of Wales the following year. Its use was widespread till the end of the nineteenth century, a welcome alternative to cautery. The composition was "a strong solution of gallic acid and spirit of roses with perhaps a little zinc sulphate."

co Jacob Hemet came from a family of dentists, two of whom, both named Peter, held royal appointments. Jacob started out life as a merchant but soon turned to dentistry, becoming Operator for the Teeth to Queen Charlotte on 7 June 1766. At this time his address was Little Tichfield Street, near Oxford Market in London. He continued to be a leading London practitioner until his death in 1790. (See J. Dobson, 'The royal dentists', Ann. R. Coll. Surg., 1970, 46: 277-291.)

Hemet's "Essence of pearl" and "Pearl dentifrice" were two of the few dental products actually patented in the eighteenth century. They had been on the market fourteen years by the time Blair advertised them and were very extensively sold. The "Essence" was composed of "amber, alcohol, benzoin, "native mineral alkali, the odorous particles of the flowers of oranges and roses extracted by watery infusion', an 'essential and vegetable salt', 'Vitrifiable earth', and orrice root, the fruit of the aromatic aracus". These different ingredients were "digested" and "that which comes over by distillation is the essence of pearl".

The pearl dentifrice was made by thoroughly incorporating together the insoluble particles which remained after making the essence, "adding to them the aromatic substances mentioned above". (B. Woodcroft, Abridgememts of specifications relating to medicine, surgery and dentistry . . 1620 1866, London, Eyre \& Spottiswoode, 1872.) 


\section{James Blair (1747-1817), provincial dentist}

Toothbrushes of the best pattern ${ }^{57}$

Dragon's blood roots's

Directions for using the Tincture and Dentifrice will be delivered with them.

This advertisement was repeated throughout July and for the first fortnight of August. ${ }^{59}$ Whatever his motives were for setting up as a dentist in the first place, he soon decided to extend the service he could offer his clients, as is seen from the following, which appeared in the paper on 8 December of the same year with three repeats: ${ }^{\circ 0}$

\section{BLAIR, Dentist Leicester}

Begs leave to inform the Public, that he has been at Nottingham for some time receiving instructions from Mr. BOTT, ${ }^{11}$ whose reputation in this art is so well established and so generally

Hemet claimed the "balsamic qualities" of his products would "preserve the teeth from decay and ... prevent those injured by neglect from becoming worse, shield them against all putrefaction, fasten such as are loose, make the foulest breath sweet".

67 Tooth-brushes were being manufactured commercially by firms such as Addis in the 1780s, but they were still very much a rarity. Not surprisingly, their design differed little from their modern counterparts, the handles and heads being of bone or ivory with the bristles secured by wire. Appealing as they did to the wealthy and fastidious, tooth-brushes often came in elegant silver cases and were sold as trinkets by perfumers and toymen. They sometimes formed part of a silver toilet set which might also contain a tooth-pick. The handles were then in silver and the heads replaceable. In a supplement to his $A$ treatise on razors (London, 1797) Bernard Kingsbury says: ". . . the common tooth-brushes, sold for $3 d .4 d$. or $6 d$. each, are badly made and highly disagreeable; . . . the hair, of which they are composed, is in itself of the worst quality, and rendered yet more unpleasant by the whiting with which it is loaded under pretence of cleaning it, and which, partaking of the nature of lime, tends rapidly to destroy it; . . . . from this cause, and from the unskilled manner in which it is put in, it becomes loose in the mouth almost as frequently as it is used; . . . . Even death itself, in instances well authenticated, has been the fatal consequence." Moving on to the virtues of his own brushes Kingsbury continues: "Their superior excellence arises, partly, from the superior quality of the materials which are used in the manufacture of them; for even the hair, the wire, and the wax itself, employed in the structure of these brushes, are much better than those which contribute to compose the common ones .... THE MANNER IN WHICH THE HAIR OF THESE BRUSHES IS DRAWN IN demands a so much greater portion of time and attention as to be utterly unattainable at the common prices; and is, likewise, in itself so peculiar as to have been, probably, unthought of, and most assuredly unattempted, by other manufacturers." He cannot claim that "of the many thousand brushes he manufacturers, each is distinguished by a superior degree of excellence. Unfortunately, the best wire will sometimes break, or cut the hair which it was intended to secure." However, "each of them will last longer than a dozen or two of the common ones." He is willing "to exchange, with pleasure, such of his brushes as become loose in the course of fair use, and are returned to him for that purpose. From this number he excepts those only which may appear to have been used with a tooth-powder or tincture in any degree vitriolic .... . Besides the patterns in common use, there are some peculiar to the advertiser. There are, also, some particularly calculated for children, for the inside of the mouth, for hollow teeth, \&c. Orders, likewise, for brushes of any pattern will be executed at short notice."

s8 "splayed marsh mallow root" used for cleaning the teeth (Berdmore, op. cit., note 43 above, p. 249).

30 LJ 14 July, 21 July, 28 July, 4 August, 11 August 1787.

60 LJ 15 December, 29 December 1787; 5 January 1788.

'1 George Bott 1748-1820 started his working life as a wool-sorter and comber in Nottingham, but by 1776 had become a vendor of patent medicines including his own corn-salve. By 1778 when he moved to a new shop in Beast Market Hill, he had already begun to practise bleeding, toothdrawing, and the fitting of artificial teeth. He claimed to have been instructed in the art of extraction by "one of the most celebrated dentists in England" but does not specify which. He carried on an extensive dental practice and was described in 1800 as "a man very eminent in his profession and carrying it out to a considerable extent as to emolument". Over a six-year period he had received 


\section{Christine Hillam}

known as to need no encomium; and that he now flatters himself the improvement he has attained under so able a master, has well qualified him to perform operations on the Teeth and Gums in such a manner as to give satisfaction to those Ladies and Gentlemen who will do him the honour to employ him

His prices are as under:

Cleaning the Teeth - - - - Five Shillings

Making a Complete Set - - - - Twenty Guineas

One Row - - - - Ten Guineas

Transplanting a Tooth - - - - Two Guineas

Crowning a Tooth - - - with a natural one - - - One Guinea

An artificial front upper Tooth - - - - One Guinea

Any other Tooth, each - - - Half-a-guinea

Filling a hollow Tooth with Gold 5s. - - - Silver $2 / 6$

NB His Tincture for the Scurvy in the Gums, 1s the bottle

Toothpowder for cleansing and preserving the Teeth is the Box - - and a variety of Tooth Brushes by the best makers.

Evidently he now considered himself a fully-fledged dentist after his stay in Nottingham, although his training could only have lasted a few months at the most (The wording of the references to Bott is found elsewhere in advertisements by most other ex-pupils of the Bott family. ${ }^{\text {(2) }}$

One imagines James Blair to have found a ready market for his dental skills. Certainly he appears to have felt no necessity to advertise in Leicester for a while and the only advertising dentists to visit the town during the first five years of Blair's new venture were Jeffs ${ }^{\text {es }}$ and George Bott. ${ }^{\text {t4 }}$ He considered himself primarily as a dentist and appeared as such in two directories for Leicester of the period. 65,68

However, dentistry was by no means Blair's only activity. In $1792^{67}$ he thanks the "Nobility, Gentry, and a kind Public" for their custom "during the time he carried on the joint business of Dentist, Perfumer and Hair-Dresser." He is grateful for "the very great encouragement and success which have attended his practice as a Dentist" and "has declined the Hair-Dressing business" (in favour of a former apprentice, Francis Moore) "in order that he may attend more assiduously to that profession,

$£ 1500$ in payment for treatment for one of his female patients. Unhappily, this was information supplied in court when the lady's husband sued Bott for "criminal conversation". This misdemeanour, which he strenuously denied, led to his expulsion from the Society of Friends.

Bott's reputation and standing in Nottingham were obviously high. He was a visitor to the Nottingham General Hospital and on its Committee. Early in his career, in 1776, he founded the Bott's Benevolent Society for the relief of the poor.

Apart from James Blair, he trained a number of dentists, including Flint who thought it worth mentioning that he was "late apprentice to Mr. Bott". Two of his sons and a daughter-in-law also became dentists. Two of his sons-in-law were surgeons, one of them a collateral descendant of the famous Fothergill.

It is interesting that Blair considers Bott's reputation for dentistry "so well established and so generally known". Certainly George Bott had been publicizing his corn-salve regularly in the Leicester press since 1776 but had never advertised in the papers that he was visiting the town as a dentist, and this at a time when his visits to Birmingham were announced in Aris's Birmingham Gazette.

o2 ABG 9 March 1795. Advertisement for Twyford, a former pupil of George Bott, junior.

es LJ 2 February 1788.

as LJ 15 November 1788.

as Universal British directory, 1791.

ce Richard Weston's Leicester Directory, 1794.

17 LJ 22 January 1792. 


\section{James Blair (1747-1817), provincial dentist}

in which he flatters himself that the knowledge he has attained, and his continued exertions to give satisfaction, will ensure his future success. . . . He means to retain the Perfumery business in all its branches, both the wholesale and retail, as usual, and will use his utmost endeavours to supply his Customers with the best of Powders, Pomatums, and every other article therein, on the most reasonable of terms."

Some idea of Blair's stock-in-trade may be had from an advertisement for another of his former apprentices, William Johnson, who, as a hairdresser and perfumer, sold "perfumes, trinkets, Dutch and English toys, Umbrellas, oil case hoods, aprons and hat cases". ${ }^{88}$

It is of some interest that James Blair's dental charges had not risen between 1787 and 1792. As Burnett has pointed out, ${ }^{80}$ it was the price of basic commodities such as bread and potatoes which rose during the eighteenth century, not those of luxury goods. "The further removed the commodity was from being a sheer necessity, the smaller the rate of increase."

Yet another business interest of Blair's was his register office. This was not the first such employment agency in Leicester. W. Cart had opened one in 1775, ${ }^{70}$ but the fact that he does not advertise again would suggest that it was short-lived. In April $1795^{71}$ Blair, (or his family, since it emerges that he himself was out of Leicester at the time) was able to find places immediately for "a professed cook -a coachmana Gardener- Several Footmen, -some must be capable of Hairdressing. . . a Nurse Maid who has no objection to travel", among others. The office was still thriving in July:"2 "Servants of all Descriptions who can bring good Characters, may . . be suited with positions. The terms of Application are One Shilling. All Letters must be Post Paid."

The final mention of Blair's Register Office came in September. ${ }^{73}$ Couched in rather cryptic terms the advertisement sought only "Men and Women Servants" and continued "As a duty is now charged at the Stamp Office on every. Servant or Place specified in the Newspaper Advertisements, were the servants implied in it mentioned singly ... [the duty] would amount to the heavy expense of some Pounds; J. Blair hopes the general Manner in which the above is expressed will not deter servants of every Description from applying as at this Time the places he has to dispose of . . . are numerous . . . [and] in great variety." (He had pointed out the previous month that "the time . . . [is] at hand when servants are either re-hired or change their places". ${ }^{74}$ )

All through this period he was also developing the jewellery side of his business. His 1792 advertisement had described him as a dentist, jeweller, perfumer, and toyman. He was more specific by 1797. In March of that year" ${ }^{75}$ he had "the best plain Hair Powder at one shilling per Pound, and the Violet at Fourteen pence. . . .

\footnotetext{
${ }^{68} \mathrm{LJ} 22$ June 1792.

'o Burnett, op. cit., note 27 above, p. 139.

70 LNJ 30 September 1775.

${ }^{7}$ LJ 10 April 1795.

${ }^{2}$ LJ 17 July 1795.

72 LJ 25 September 1795.

24 LJ 14 August 1795.

${ }^{76}$ LJ 3 March 1797.
} 


\title{
Christine Hillam
}

He will have, at the Assizes, . . . in addition to his present stock, a good Assortment of elegant Jewellery goods." In September "he expects to receive from London, on Saturday next, an elegant and fashionable Assortment of Ear-Rings, Necklaces etc. for the Races". ${ }^{76}$ The following year he obtained "a few well chosen Articles" for the Races. ${ }^{77}$ In 1799 he combined with his daughter Charlotte (by now a milliner) to provide his clients once again with "a diversity of Elegant Articles" for this fashionable season in the Leicester year. ${ }^{78}$

Thus it would seem that during his remaining years in Leicester, although he spent an increasing amount of his time as a dentist and abandoned hairdressing, he by no means relinquished all his other activities and in fact extended his jewellery interests. His fees for dental treatment were certainly not exorbitant by contemporary standards but the strata of society who were in a position to afford them must have been very limited.

So thinly dispersed were Blair's potential patients that, like other dentists, he was obliged to travel to find them. For much of the 1790 s he appears to have spent a considerable amount of time out of town. Retaining his Gallowtree Gate shop as his permanent home, he for several years undertook two tours a year, each lasting some weeks. His return to Leicester was sometimes announced in the local press and one imagines that during his absence his wife carried on his multifarious trading activities.

His first advertisement in a new town in the 1790s followed a common pattern. After describing how he removed tartar and scurvy from the gums and fitted artificial teeth "without the least degree of Pain and in such a Manner, as not to be distinguished from natural ones", he would continue in the following vein:

\begin{abstract}
He also begs leave to observe, that too great an attention cannot be paid to the Teeth of Children, between the age of Six and Fourteen. The utmost Care is absolutely Necessary at the time of changing the Teeth, for it too frequently happens that the old Teeth, by continuing too long, force the young ones into a wrong Direction, and that sometimes to such a degree, as to cause the Appearance of a double Row. This is truly unbecoming, and the timely Assistance of a Dentist should be called to remove or prevent it; for if it is suffered to remain any length of Time, it will not be in the Power of the ablest Artist to cure the Deformity; and the Person who is so unfortunate as not to have proper Assistance at this critical Period, will ever be subject to all the Inconvenience which proceeds from a bad set of Teeth. [He adds, optimistically,] It is almost unnecessary to add, that where due Attention has been paid to the Teeth at an early Age, and particularly at the Time of shedding them, a very small Degree of Attention to cleaning, etc., is afterwards sufficient to preserve their Soundness and Beauty even to Old Age. ${ }^{10,00}$
\end{abstract}

Blair's main emphasis, at this period, appears to have been the regulation of children's teeth, an aspect of treatment not mentioned in his Leicester advertisements, which ceased, in fact, once he had become established. Perhaps he had found that more people were prepared to spend a relatively small amount on their children than there were clients who had twenty guineas to spare for a complete set of artificial teeth for themselves. He reveals himself as an astute advertiser, encouraging his

16 LJ 15 September 1797.

77 LJ 14 September 1798.

72 LJ 13 September 1799.

70 Manchester Mercury (hereinafter referred to as MM) 27 May 1794.

0 Chester Chronicle (hereinafter referred to as CC) 15 June 1798. 
readers' hopes and confirming their worst fears. In 1799 he urges the parents of Denbigh, "as they value the comforts of their children, ... to examine the state of their teeth from six to fourteen years of age and should they perceive any irregularities, to make immediate application, as they are during that age, for the most part, easily regulated". ${ }^{81} \mathrm{He}$ employed a similar technique with regard to claims for his tooth-powder which "needs no Encomium. Time and Experience have sufficiently convinced the Public of its Efficacy and Innocence." The only precaution required was "not to brush the Teeth too much crossways, but upwards and downwards, and as near the Gum as possible. This will completely prevent the Tartar from accumulating, fix the Gums to the Teeth and by those means preserve them from Loss and Decay. When the Teeth are actually encrusted with Tartar, recourse should be had to a Dentist, for the removal of it, as no Application whatever ... can make the Gums unite, whilst any Tartar remains". 79

As at Leicester, once he had established a clientele, such advertisements cease and only details of dates of attendance in the town are given and perhaps the names of local agents for his tooth-powder.

Blair's first foray to the north-west of England appears to have taken place in 1794, when he stayed at Mr. Williams's, 36 Oldham St., Manchester, for ten days from 27 May. Not that this was the first time he had travelled away from Leicester, for in his advertisement he names as agents for his tooth-powder shopkeepers in London, Bath, Oxford, Reading, Rothley, Northampton, Bedford, Derby, Loughborough, Stamford, Oakham, Huntingdon, Wisbech, and Oundle. The sale of such products in Leicester seems almost always to have been preceded by a visit by the dentist himself and thus it seems not unreasonable to assume that Blair had in fact practised in these towns before 1794 and established his contacts there in person.

On his next visit to Manchester in April 1795 he was "particularly desirous of suggesting . ... that the temperate Season of Spring is particularly favourable to all Operations on and Treatments of the Teeth". ${ }^{82}$ This favourable season seems to have been a movable feast as in $\mathbf{1 7 9 6}$ he was recommending August as particularly auspicious, ${ }^{83}$ whereas in 1797 June was considered the most suitable. ${ }^{84}$ Natural order was restored the following year when April once again gained supremacy ${ }^{85}$ Thereafter there are no further references to the weather.

Blair visited different premises each year in Manchester. In 1795 he was staying at $6 \mathrm{King}$ St; in 1796 he was at Mr. Lewes's, 41 Opposite Spring Gardens, Market-StLane; in 1797 at Mr. Lea's, 2 Lever St; in 1798 he lodged with Mrs. Preston, 50 Fountain St., but was prepared to visit clients in their own homes; finally 1798 saw him at Mr. Whitehead's, 103 Oldham St. ${ }^{82,83,84,85}$

During his stays based on Manchester he established agencies for his tooth-powder with Messrs. Olivant, silversmiths, Mrs. Sykes, perfumer, Mr. Lynch and Mr. Staines, druggists, Miss Cheshyre, milliner, and Mrs. Greenwood in Rochdale.

In November 1796 Blair paid his first advertised visit to Cambridge, staying at

81 CC 7 June 1799.

12 MM 7 April 1795.

82 MM 2 August 1796.

84 MM 13 June 1797.

es MM 17 April 1798. 


\section{Christine Hillam}

Mr. Readhead's in St. Andrews St. for about two weeks before visiting Bury St. Edmunds for two days. ${ }^{86}$ No earlier advertisement has been found for him in the Cambridge Chronicle, but he already had six agents for his powder in the town, one in Bury St. Edmunds, two in King's Lynn, two in Wisbech, and one in Huntingdon. The last two towns had featured in his first Manchester advertisement in 1794 but the others were presumably acquired between 1794 and 1796. Exactly a year later he was back at the same address in Cambridge for a stay of three weeks. ${ }^{87}$ Bringing "an excellent assortment of Tooth Brushes" he returned to Mr. Readhead's in November $1798 .{ }^{88}$ His three-week stay in 1799 was at Mr. Hodge's, the baker's, near Great St. Mary's Church. ${ }^{80}$

In 1798 Blair began to include Chester on his north-west tour. Staying at Mr. Isaac Trevor's, in St. Werburgh's Lane, for about a month from 15 June, ${ }^{80,80}$ he ventured into Wales, visiting the "Red Lion", Wrexham, for two days during this period. He paid a return visit to Mr. Trevor's the following May, ${ }^{21}$ bringing with him "an excellent assortment of SILVER WIRED, and other TOOTHBRUSHES." This visit lasted six weeks, and included a two-day excursion to Denbigh where he lodged at the "Crown Inn". In these two years he established agencies for his toothpowder with Mrs. Green, perfumer, and Mr. Paul, a druggist.

The first intimation that Blair was in the habit of visiting London appears in the Leicester Journal for 18 January 1799. Thereafter it was his custom to travel to the capital in December or January. However, searches of the London press for the periods when Blair states he was there have not yet revealed any advertisements relating to him.

There are no indications of Blair's absence from home in the Leicester press until August $1798^{\circ 2}$ when he informs his customers he has just returned from Manchester and Chester and will be remaining in the town until the middle of October. In January of the following year he announces that "Being returned from Cambridge and London ... he intends to remain in Leicester 'till April, after which Time he will visit Manchester and Chester for a few Months." By consolidating the information given in his advertisements in Leicester, Manchester, Chester, and Cambridge it is possible to arrive at an outline picture of his movements between about 1792 and 1799:

PRE-1794: Some contact with London, Bath, Oxford, Reading, Rothley, Northampton, Bedford, Derby, Loughborough, Stamford, Oakham, Huntingdon, Wisbech, and Oundle.

1794: 27 May-5 June Manchester.

1794-1796: Contacts established in Bury St. Edmunds, King's Lynn, Cambridge.

1795: 7 April + Manchester (length of visit unspecified).

1796: $28 \mathrm{July}+$ Manchester (length of visit unspecified).

28 November-12 December Cambridge.

14 December Bury St. Edmunds.

36 Cambridge Chronicle (hereinafter referred to as CaC) 3 December 1796.

$37 \mathrm{CaC} 2$ December 1797.

$38 \mathrm{CaC} 17$ November 1798.

2030 November 1799.

* CC 6 July 1798.

1 CC 3 May 1799.

is LJ 10 August 1798.

• LJ 18 January 1799. 


\section{James Blair (1747-1817), provincial dentist}

1797: 2 June+ Manchester (short visit, because of numerous engagements).

1798: $\quad 17$ April+ Manchester (length of visit unspecified).

15 June-14 July Chester.

9-10 July Wrexham.

10 August-mid October Leicester (states he has just returned from Chester on 10 August).

13 November+ Cambridge (length of visit unspecified).

1799: 18 January-April Leicester (states he has just arrived from Cambridge and London on 18 January).

29 April-18 June Chester.

10-11 June Denbigh (has other engagements).

30 July-19 August Manchester (states he returns to Leicester on 19 August).

29 November-18 December Cambridge.

It will be seen that there are certain periods unaccounted for in Blair's advertisements, as in 1798 when he states that "engagements at Leicester oblige him to leave Chester on Saturday the 14th [July]" but does not announce his arrival in Leicester until 10 August. Perhaps he was in the habit of taking a few weeks' rest after one of his tours or it may be that further investigation of the eighteenth-century press of Stafford, Derby, Northampton, Stamford, and elsewhere would reveal him calling in at other towns on his route home from Chester, either to practise dentistry or to deliver supplies of his tooth-powder.

\section{FULL-TIME DENTIST}

By the end of the century Blair had certainly fulfilled his declared intention of 1792 to "attend more assiduously" to dentistry, even though this had obliged him to spend a minimum of three months of the year away from home. In 1800 he appears to have made the decision to trade exclusively as a dentist and relinquish all his other commercial interests. However, it must have been evident that to do this he would have to leave Leicester. Had there been sufficient continuous demand for dental treatment in the area Blair would presumably never have needed to take to the road twice a year in the first place. The fact that he had been able to practise as a dentist in Leicester for thirteen years and continued to visit the town annually for a number of years after he moved, rules out the possibility that he was obliged to leave because of a bad professional reputation. Similarly, there seems to have been no domestic circumstance which might have prompted his removal, nor does he appear to have had any family connexions in the areas to which he moved. The Leicester press frequently carried notices concerning local bankruptcies but no such announcement appears for James Blair. One is forced to conclude that his motives for moving were commercial.

The possibility of leaving Leicester after twenty-nine years first occurred to Blair in 1798. In September of that year he advertised that "intending to remove from Leicester" (no other town is named) he was offering for sale his "Stock of Jewellery, Toys, Perfumery, wishing to dispose of them prior to his Removal". ${ }^{77}$ However, for some reason he changed his plans and did not leave for another two years.

The actual move was preceded by the sale of Blair's "Genteel and Useful HOUSEHOLD FURNITURE" on Tuesday 25 March 1800. The auctioneer obviously expected the proceedings to last several days and produced a detailed catalogue 


\section{Christine Hillam}

obtainable at the principal inns in Leicester.9 Examination of the list of Blair's effects which appeared in the local press 95 reveals the high standard of living he had achieved during his years in Leicester. "The household furniture consists of four post, Tent and half head bedsteads, clothed with striped Manchester, Harateen, Check and other hanging, fin[e] fur and feather beds, Mattrasses [sic], large Blankets and Counterpanes, Mahogany Dining, Card, Screen, Dressing and Night Tables, Mahogany chairs, Mahogany Escritoire and book-case, Oak Wardrobe, chest of drawers, dressing table and chairs, Wilton and Scotch carpets, Pier and Swing glasses, 8 day clock by Linley, in oak case, sundry glasses, tea china, books and kitchen requisites etc. etc." The "valuable collection of Paintings" and "Prints will be sold on the 3rd day's sale". On the first day of the sale would be sold any remaining stock "together with the capital shop fixtures, shew glasses etc." As there is no evidence that Blair was in any financial difficulties, one imagines that such a radical sale was occasioned by the limitations of contemporary transport.

As much of Blair's business was now centred on the expanding north-west, Chester, where he had received "such kind encouragement and promises of support", 96 seemed an obvious choice as a new base from which to practise dentistry. Since the departure of Jean Joseph (Armand) Talma in about 1797, Chester had had no resident dentist and received only the occasional visit from itinerants. Braham, self-styled "Dentist to the University and city of Oxford" who also "eradicates corns by the use of a brush and liquid", visited the town in May 1798,97 but otherwise Blair had met with no competition at the time of his two previous visits. The same could not be said for Manchester, where there were already established dentists.

By May 1800 James Blair had moved to Chester and taken lodgings as usual with Mr. Trevor, in Werburgh's Lane.96 Two months later he had taken a house in Watergate Street, opposite Trinity Church. He moved in on Monday 7 July.98

Not that Blair spent all his time in Chester. Soon after his arrival he had announced that he would normally be in Cambridge during November and December. ${ }^{96} \mathrm{He}$ set off on his first visits before he had even obtained a permanent address, calling at the "Red Lion", Warrington for three days from Wednesday 11 June with a return visit of three days in September.99 After this he paid a number of visits to the town: 30 March-3 April and 11-19 November $1801 ;^{100,101} 1-5$ November $1802 ;^{102}$ and 18 April 1803. ${ }^{103}$

He evidently intended to develop the contacts he had made over the previous nine years in Manchester. Visiting the city in August 1800 (and staying at 11 Piccadilly) he declared that from now on he intended visiting Manchester three times a year. However, only one further advertisement can be found for him in the Manchester

\footnotetext{
* LJ 28 February 1800.

os LJ 7 March 1800.

- CC 9 May 1800.

-7 CC 11 May 1798.

๑CC 4 July 1800.

- MM 23 September 1800.

${ }^{100}$ CC 27 March 1801.

102 CC 6 November 1801.

102 CC 29 October 1802.

100 CC 15 April 1803.
} 


\section{James Blair (1747-1817), provincial dentist}

press, and that in the following year. ${ }^{104}$ By this time Flint, a former pupil of George Bott's, was visiting Manchester, ${ }^{105,106,107}$ as were Sedmond ${ }^{108}$ and Mrs. Davidson, ${ }^{109}$ both from Bath. With competition from other itinerants and from Thomas Faulkner and "J. Bott", who claimed to be a distant relative of the Nottingham dentist, 110 Blair may have felt it was not worthwhile to continue his visits.

Blair stopped visiting Cambridge after 1800 . His visit that year was in any case a brief one - only a week - as he had "indispensible engagements elsewhere". 111 In compensation, he established new contacts. In August 1802 he paid a four-day visit to Holywell, Denbigh, and St. Asaph, ${ }^{112}$ and a similar one of three days in July 1803 to Parkgate, then a fashionable resort on the Wirral. ${ }^{113}$

At the same time, from 1803, he was in the habit of calling in at Leicester on his return from London in January or February, sometimes for as long as three weeks. ${ }^{114}$ At first he stayed with his daughter Charlotte who, in her millinery business in High Street, had continued to sell her father's tooth-powder and brushes ever since he had left the town. After her marriage in 1804 (to a Ridlington farmer, Nathaniel Wortley) Blair began to stay with Mr. Metcalf the grocer, opposite his old house in Gallowtree Gate. ${ }^{115}$ Giving about a week's notice he would invite prospective clients to leave their "commands" for him. Now that his daughter was no longer his agent in the town, new sellers had to be found and the powder advertised in the press, usually just after one of Blair's visits. In $\mathbf{1 8 0 5}$ he assures his clientele that the product is sold as usual in Leicester and that "wherever it is known, it maintains its Distinction with the pompous Declarations attendant on similar Preparations". 116

His 1807 advertisement ${ }^{117}$ reveals something of the pattern of his visits to a town. Having arrived on 12 February he found he had engagements "in the country" which meant that he could only be consulted in Leicester on 20, 21, 27 and 28 February and on 5,6, and 7 March. The rest of his fortnight's visit was presumably spent in visiting clients' homes in the surrounding area.

However, the most fruitful new market proved to be Shrewsbury. Blair visited the town for the first time in May 1801, staying with Mr. Lloyd, a glover in Shoplatch.118 He returned to the same address in September of the same year ${ }^{119}$ and in May 1802. ${ }^{120}$ Thereafter he stayed with Mr. Vincent, a tinman and brazier in the same

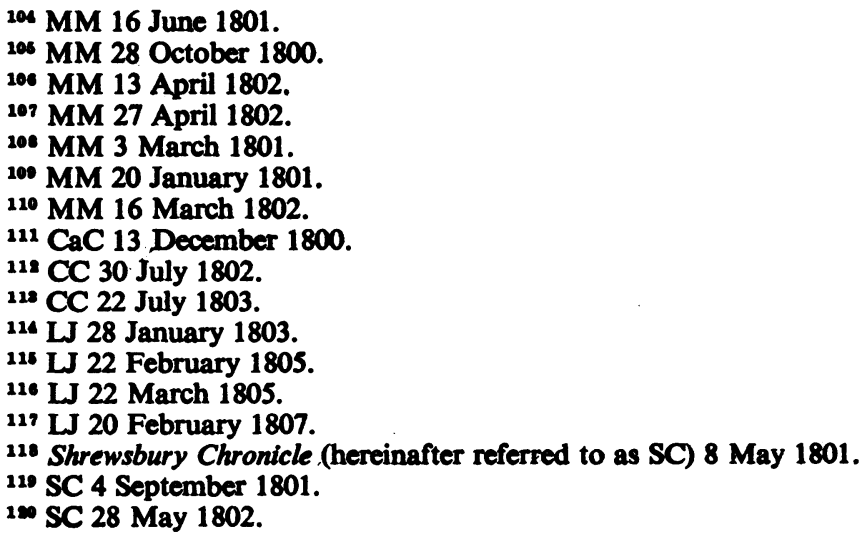




\section{Christine Hillam}

street, returning to Shrewsbury every May and September. Each visit lasted, on average, a fortnight, and might be succeeded by a short visit to the "Cross Keys" at Oswestry. This was the case in $1801,{ }^{121} 1803,1221806,{ }^{123}$ and 1807.124 Blair paid a similar two-day visit to the "White Lion" at Whitchurch in September 1803 on his way back to Chester. ${ }^{125}$

In all these places Blair established agencies for his tooth-powder and brushes, usually with hairdressers and perfumers (Nightingale and Hulme at Shrewsbury) or a bookseller and printer (Jameson at Oswestry).

\section{LIVERPOOL, 1807-1817}

After seven years based on Chester, Blair was once more ready for a move, this time to Liverpool. Again, no domestic or financial reasons can be found for this removal and one can only assume that there was no longer an adequate supply of new patients to warrant his spending approximately nine months of every year in the town. Certainly one feels the situation must have been a serious one and the alternative very attractive to induce him to uproot himself at the age of sixty and move to a new city, even farther away from his Shropshire clients.

Blair's first advertisement in Liverpool suggests that he had already visited the city professionally in that he returns the inhabitants "his sincere thanks for the encouragement he has already received ... assuring them no exertion shall be wanting to merit [their commands]". ${ }^{126}$ He quotes seven agents at whose shops "his Tooth Powder is sold as usual." However, no advertisements have been found in the Liverpool press for the three years preceding his moving there permanently.

The move took place in June 1807. Blair rented 39 Bold Street, and stayed in the same house for the rest of his life. (Trade directories over the next years give the number variously as 39,41 , and 51 , but the Land Tax returns ${ }^{127}$ make it clear that the house was merely renumbered as the years went on.)

The pattern of Blair's practice in Liverpool was very much the same as it had been in Chester. To begin with he continued his visits to London. His 1809 trip was announced the previous December: "... (as is his usual custom) he purposes setting off for London, on the 16th of January next, where his Professional Engagements will detain him about a month, of which he considers it his duty to apprize those who intend to honour him with their commands, in order that they may not suffer any disappointment by his absence". ${ }^{128}$ On his way back from London he spent a week in Leicester (17-25 February). ${ }^{129}$ (His return to Liverpool was not advertised until 15 March $^{130}$ and would suggest that, as speculated before, he was in the habit of taking a few weeks off after such a trip. Alternatively, he may have found that

\footnotetext{
181 SC 18 September 1801.

18 Salopian Journal (hereinafter referred to as SJ) 25 May 1803.

1 s] 10 September 1806.

124 SJ 16 September 1807.

125 SJ 21 September 1803.

186 Liverpool Chronicle (hereinafter referred to as LC) 1 July 1807.

${ }_{127}$ Land Tax returns for Liverpool, Lancashire Record Office, QDL Liv.

128 Liverpool Courier (hereinafter referred to as LCo) 21 December 1808.

180 LJ 17 February 1809.

120 LCo 15 March 1809.
} 
business needed the stimulus of advertising after one of his absences.) There are no further advertised visits to either London or Leicester. Perhaps he was finding the thirty-eight-hour coach journey to the capital too much for him at this stage.

However, Blair's travelling days were by no means over. On leaving Chester he had thanked his patients most profusely and requested "their future patronage, assuring them that their kindness will never be effaced from his mind ... it is his intention to visit the city once in every three months (which will be announced by advertisement) ... or should they want his immediate assistance, a line directed to him, at his house ... will meet attention, and they will be waited upon the next day, if possible". ${ }^{131}$ (Five agents are quoted for his dental products.) This plan he effected, although his visits were not always so frequent as he had anticipated. For the rest of his life he visited Chester every year, staying at Mr. Trevor's (who had now moved to Abbey Court) or at Mr. Hunter's, an engraver and gilder in Newgate Street.

The first such visit was a short one (13-16 April 1808), but he was back on 13-16 July and 17-20 October. Subsequent visits followed a similar pattern:

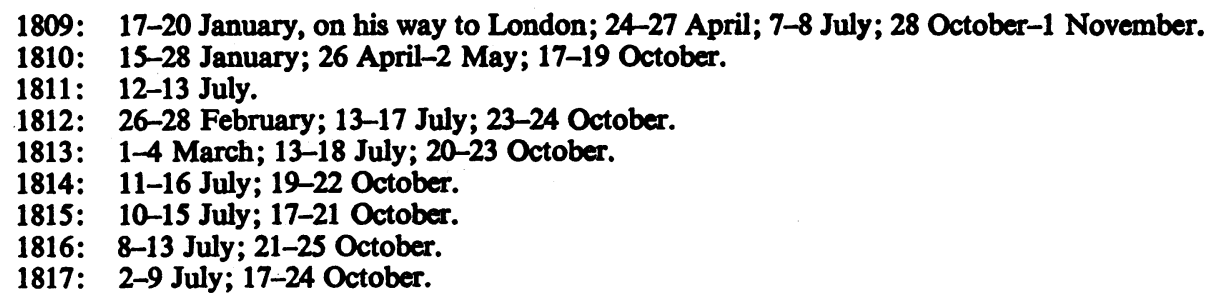

Similar visits were paid twice a year to Shrewsbury, in May and September. Notices of his intended visits to both towns usually give his present location as Liverpool. No details of treatment appear, merely the dates and places of his arrival. Nor are there any indications after 1809 in the Liverpool press of his absence from home, which would suggest either that he was not working single-handed or that he was so well established as not to need to advertise.

His movements during 1812 are representative of the pattern of his practice at this period:

February: 26-28 Chester.

May: 4-16 Shrewsbury.

July: $\quad$ 13-17 Chester.

September: 17-28 Shrewsbury.

October: 23-24 Chester.

\section{SUBSEQUENT HISTORY OF THE PRACTICE}

James Blair died at his home in Bold Street, Liverpool, on 26 December 1817, aged seventy. He was buried at Holy Trinity Churchyard, St. Anne's Street, in the city. ${ }^{132}$ Notices appeared in the Shrewsbury and Leicester press. The Liverpool Mercury stated: "His death will be severely felt and lamented by those to whom he

181 CC 19 June 1807. Office.

${ }^{182}$ Register of burials, Holy Trinity Church, St. Anne's Street, Liverpool, Liverpool Record 


\section{Christine Hillam}

was endeared by a long series of faithful and assiduous professional services". ${ }^{133}$ The Chester Chronicle went further: "He has not left behind him, one who possesses more integrity or kindness of heart towards his fellow creatures". 134

Shortly before his death, Blair had taken into partnership Thomas Whitfield Lloyd, a former cutler and the son of a surgical instrument-maker. Mrs. Blair announced in the Liverpool press that the business would be carried on "for the benefit of herself and Mr. Lloyd" 135 adding in a Chester advertisement that "Mr. Lloyd will attend at Chester, Shrewsbury etc. at the usual seasons". ${ }^{136}$ This he did, making the same visits as Blair had done, but under the name "Blair and Lloyd".

This agreement between Martha Blair and Thomas Lloyd expired in December 1823. Lloyd then moved to 59 Bold Street where he set up his own practice (later carried on by his sons and grandson until 1918 and still in existence today). He continued to visit Shrewsbury until the 1840s.

Martha Blair entered into a new agreement with a Mr. Turner from London. ${ }^{137}$ This did not prove a happy association, however, and by the following October Martha Blair, now aged sixty-eight, sold her household effects, including the eight-day clock and "a quantity of SEA HORSE TEETH" and moved to Birmingham to live with her married daughter, Jane Robertson. ${ }^{138}$ She died in Birmingham on 30 December 1829. 139

Neither wills nor administrations can be found for either James or Martha Blair. This is a matter of some surprise since one imagines that Blair made a considerable amount of money as a dentist. He could surely not have continued visiting the same towns year after year had he not been successful. Also, Blair was survived by a widow and an unmarried daughter and one would have thought he would have wanted to make some specific provision for them. Perhaps the fact that his visits to market towns so often coincided with race meetings holds the key to the enigma.

8. DENTAL AND MEDICAL DESCENDANTS OF JAMES BLAIR

1. James Blair (1847-1884): son of Edward John Blair and grandson of James Blair (Blair's eldest child, a solicitor in Uttoxeter until the 1850s). He appears in the Dentists' Register for 1879 and 1881 as having been in practice before 1878, but his whereabouts before this date have not yet been discovered. He died in North Stafford Infirmary, Stoke on Trent, of phthisis. He is described on the death certificate as "Dentist of Uttoxeter".

2. Henry Blair Robertson (1826-1853): son of Blair's daughter Jane, who was married to her cousin, the dentist William Robertson. The careers as dentists of Henry Robertson and his half-brother James (1817-1867) have already been examined in a recent paper. ${ }^{140}$

19 Liverpool Mercury (hereinafter referred to as LM) 2 January 1818.

124 CC 2 January 1818.

128 LM 16 January 1818.

120 CC 23 July 1818.

${ }^{137}$ LM 19 December 1823.

188 LM 1 October 1824.

130 LM 1 January 1830.

140 R. A. Cohen, E. A. Marsland, Christine Hillam, 'William Robertson of Birmingham 1794 1870', Br. dent. J., 1977, 142: 64-69, 99-102. 
3. Thomas Bell: son of Catherine Blair (daughter of James Blair, solicitor in Uttoxeter) and John Bell, a surgeon in Uppingham. L.R.C.P. London (exam) 1861; M.R.C.S. Eng. 1860 (King's College). First registered 4 June 1861. Member of the British Medical Association. Medical Officer to Uppingham Union Workhouse and District Public Vaccinator. Sanitary Officer to Uppingham School. Author of a contribution to the Lancet of 1899 entitled 'A woman disembowelled by a cow - recovery'. He continued to practise in Uppingham until 1914.

4. Kenneth de Risley Bell: son of Thomas Bell. L.R.C.P. and M.R.C.S. 1898 (King's College Hospital). M.D. Brux. 1900. First registered 30 April 1898. Practised initially in Uppingham but in 1909 moved to Lambourn, Berkshire, where he stayed until 1931. He subsequently lived in Bognor Regis until 1935. He retired in 1939.

5. Mary Cecilia Bell: daughter of Thomas Bell. M.B., B.S. London 1903 (London School of Medicine for Women). First registered 17 December 1903. Member of the Association of Registered Medical Women and the Society for the Study of Inebriety. Fellow of the Royal Society of Medicine. Resident Medical Officer at Wycombe Abbey School, High Wycombe, 1904. Resident Medical Officer at the Jenny Lind Infirmary, Norwich, 1905-1907. She stayed in Norwich until 1917-18 when she moved to Harley Street. Remaining in London until the mid-1930s, she retired to Cranbrook in Kent where she lived until 1964.

JAMES BLAIR 1747-1817

m. 1

Charlotte Jordan

1750-1781

$\left.\right|_{\text {James Blair }}$

(solicitor)

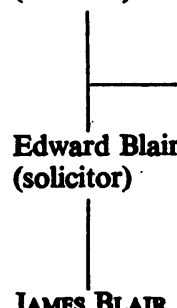

(dentist) m. 2

Martha Hodgkin

1756-1829

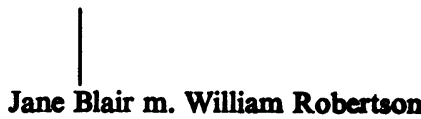

(dentist)

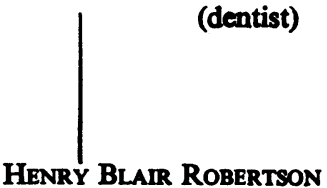

(dentist and surgeon)

\section{JAMES BLAIR, DENTIST, IN HIS CONTEMPORARY CONTEXT}

The surprising thing is not that Blair advertised as a dentist in 1787, but that he did not do so earlier. As a barber in Edinburgh with Gilbert Blair he must have come into 


\section{Christine Hillam}

contact with the tooth-drawing aspect of the trade. (Berdmore, writing in 1768, speaks of the large numbers of teeth extracted by barber dentists.) ${ }^{141}$ It may well be that in the fashionable circles in which Ritchie of Rupert Street moved tooth-drawing had been divorced from hairdressing, but even he advertised in 1774 that he "had studied Anatomy under Dr. [William] Hunter, scales and cleans teeth, etc., in a safe and easy manner, makes tender, spongy or bad gums, firm, hard and good, and removes all causes of tainted breath, by certain, gentle and innoffensive methods". ${ }^{142}$ On these grounds he felt justified in calling himself "Hair-dresser, Dentist, etc."

In his capacity as a perfumer in Leicester, Blair must surely have stocked dentifrices and other dental cosmetics, but apart from announcing in 1775 that he keeps toothbrushes does not mention a single such product in his advertisements before 1787, detailed though they are. Nor is he ever quoted as an agent for any of the common patent medicines advertised in the Leicester and Nottingham Journal before that date.

One feels that Blair would certainly have had some sort of experience of dentistry before his arrival in Leicester in 1769, either in the form of tooth-pulling or of selling patent products for beautifying the mouth. One may conclude either that he simply did not practise dentistry (although there must have been some demand for it from the wealthy in an area without a dentist and scarcely any visiting practitioners) or that he considered this aspect of his business too obvious or too insignificant to mention in his advertisements.

Blair's first announcement as a dentist (in July 1787) is typical of the eighteenthcentury empiric and the treatments he offers quite standard. Mr. Moor from Bath similarly declared that he "fastens loose Teeth". ${ }^{143} \mathrm{Mr}$. Normansell sold an "Opiate or Powder for the Teeth . . . that . . . preserves and hardens the Gums". ${ }^{144} \mathrm{Mr}$. Wooffendale also "fixes in ... artificial teeth . . . without pain". ${ }^{145} \mathrm{Mr}$. Grimaldi, visiting Birmingham in 1773, "makes Artificial Teeth, which cannot be distinguished from Real Ones". ${ }^{146}$

Similarly, most dentists sold their own tinctures and dentifrices. Like Blair, many made a point of saying how innocuous their powders were, especially after Berdmore had published his Treatise of 1768 in which he stated that the products then on sale in London "all act directly for the destruction of the enamel, either by mechanical grinding or chemical dissolution". ${ }^{147}$ He went on to show that the enamel could be destroyed in less than an hour with a tooth-brush and any commonly used toothpowder, the basic ingredient of which was likely to be pumice stone, emery, or other cutting powder. Nor had he anything good to say about the type of tincture which was sold to whiten the teeth, "universally composed of mineral acids diluted and concealed by various artifices". ${ }^{118}$ Sound teeth left in such a liquid could be completely destroyed in three days. His opinions corroborated those of Hunter ${ }^{149}$ and were in

141 Berdmore, op. cit., note 43 above, p. 37.

148 Daily Advertiser 6 May 1774 (quoted by Campbell, op. cit., note 36 above, p. 192).

163 ABG 28 July 1777.

14 ABG 6 October 1766.

${ }^{145}$ Morning Herald 6 January 1789 (quoted by Campbell, op. cit., note 36 above, p. 194).

14 ABG 28 June 1773.

147 Berdmore, op. cit., note 43 above, p. 227.

148 Ibid., p. 236.

160 John Hunter, The natural history of the human teeth, London, J. Johnson, 1771, p. 124. 


\section{James Blair (1747-1817), provincial dentist}

turn supported by Wooffendale. ${ }^{150}$ (These were almost the only English books on dentistry available to Blair, apart from advertising tracts produced by other dentists.)

With regard to Blair's own tooth-powder, his son-in-law, William Robertson, writes "the toothpowder which I use and recommend is 'Blair's Tooth Powder'. It is well prepared and contains no ingredient which is injurious to the teeth."151 It was still being used by Robertson's son James in the 1860 s but no formula has survived.

Blair saw his powder as "a certain Preservative of the Teeth and Gums". 116 Like his more eminent contemporaries, he recognized the dangers of $\operatorname{tartar}^{79}$ and like Berdmore 152 obviously considered that brushing could prevent its formation. However, there is a certain ambiguity in his statement that correct tooth-brushing "will completely prevent the Tartar from accumulating, fix the Gums to the Teeth and by those means preserve them from Loss and Decay." (The frequently encountered claim that the gums would be reattached presumably refers to the observation that shrinkage would occur after the resolution of inflammation.) It is not clear in Blair's claim whether "them" refers to "Gums" or "Teeth". If he really means that the removal of tartar will prevent decay of the teeth, then he was in advance of his contemporaries in implicating plaque (included in the eighteenth-century use of "tartar") in the origin of caries. Both Berdmore and Wooffendale were of the opinion that caries was decalcification initiated by acids.

After his short time with George Bott in the second half of 1787, Blair becomes more specific in the description of his treatments. In addition to a range of prosthetic appliances, he now felt himself "well qualified to perform" transplantation of teeth from one mouth to another. There was at this time a relatively short-lived vogue for the operation which was given added impetus by the publication of the second part of John Hunter's Natural history of the human teeth in 1778. The author considered the technique "of no great difficulty" 153 if restricted to the anterior teeth, but neither Berdmore ${ }^{154}$ nor Wooffendale, ${ }^{155}$ with their practical experience, share his optimism. Blair makes no further claims to be able to transplant teeth after this one advertisement.

Blair was in line with the best tradition when he offered as one of bis treatments "filling a hollow Tooth with Gold." Wooffendale certainly considered this the best filling material156 and decried the use of lead. However, he warned that the cavity must be stopped so completely "as to prevent ... the smallest portion of food . . . [and] . . . even the residuum of the saliva from getting into the caries". ${ }^{157}$

Fixing new crowns to existing roots was a treatment commonly offered by Blair's fellow-dentists and endorsed by contemporary writers. Wooffendale describes the technique of "filing each [the root and the new crown] properly, and uniting them

\footnotetext{
${ }^{150}$ Robert Wooffendale, Practical observations on the human teeth, London, J. Johnson, Richards \& Urquhart, 1783.

161 William Robertson, Practical treatise on the human teeth, London, Churchill, 2nd ed., 1839, p. 139.

162 Berdmore, op. cit., note 43 above, p. 73ff.

163 John Hunter, A practical treatise on the diseases of the teeth intended as a supplement to the natural history of those parts, London, J. Johnson, 1778, p. 94.

134 Berdmore, op. cit., note 43 above, p. 102.

166 Wooffendale, op. cit., note 150 above, pp. 132-135.

166 Ibid., p. 8.
} 


\section{Christine Hillam}

by the assistance of a screw of gold or silver". ${ }^{158}$

Most of the treatments Blair offers by the end of 1787 , if not exactly simple, could at least have been learned relatively quickly at a superficial level. His patients would have been none the wiser for a while if an artificial crown was not a good fit on the root or if the ligatures with which he fastened a loose tooth were likely to endanger the adjoining teeth. However, the same could not be said of the making of sets of artificial teeth, upon which his reputation might be said to rest. ${ }^{159}$ The carving of a denture from a solid piece of ivory was a highly skilled and time-consuming job, and an unsuccessful result immediately obvious to the patient. The construction of a small prosthesis to replace a few teeth, whether carved out of ivory or consisting of human crowns set on a gold plate, might have presented him with fewer problems. As Blair had no difficulty in staying in business as a dentist in Leicester for thirteen years, it would seem that his early efforts did not bring disaster in their wake. Unless he had in fact been making artificial teeth for some years previously, one imagines that he may have employed someone else to make them for him, although at no time does he ever advertise for such an employee. When in Chester and Liverpool he rarely informs his local clients that he will be away from home. This may also be interpreted as an indication that he did not work single-handed. It is known that he entered into partnership with Thomas Whitfield Lloyd towards the end of his life.

At the end of 1787 Blair lists his charges for treatment, which are, in fact, exactly the same as George Bott's. ${ }^{160}$ The fees must have seemed a bargain compared with some of the charges made at the time. Grimaldi, the "Royal Dentist", ${ }^{161}$ on a visit to Birmingham in July $1785,{ }^{162}$ charged $10 s .6 d$. for cleaning the teeth, 10s. $6 d$. for drawing a tooth or a stump, 10s. $6 d$. for filling a tooth with lead (a treatment not offered by Bott or Blair), 5 guineas for a transplant, $10 \mathrm{~s}$. $6 \mathrm{~d}$. each for artificial teeth, 3s. $6 d$. for a box of his powder, and 5s. $0 d$. a bottle for his "antiscorbutic water".

They also compare favourably with the charges made by Paul Euralius Jullion on a visit to Bath in $1780 .{ }^{163}$ His gold fillings might be only $7 \mathrm{~s}$. $6 \mathrm{~d}$., but his fees for scaling, transplanting, and crowning were more than twice Blair's and Bott's. He charged more or less the same for artificial teeth (10 guineas for one row and 25 guineas for a complete set), but had separate charges for dentures using human teeth, $£ 31 \mathrm{Os}$. $0 d$. for one row and $£ 7310$ s. $0 d$. for a complete set. Even this was nothing compared with the fees Martin Van Butchell was able to command as early as $1777 .{ }^{164}$ Extrac-

18s Ibid., p. $140 \mathrm{ff}$.

150 Details of eighteenth- and nineteenth-century dental prostheses are to be found in Bernard W. Weinberger, An introduction to the history of dentistry, vol. 1, St. Louis, Mosby, 1948; and R. A. Cohen, 'Notes on the identification, description and dating of ivory dentures', Br. dent. J., 1962, 113: 259-263; 'Methods and materials used for artificial teeth', Proc. R. Soc. Med., 1959, 52: 775-786. ${ }_{100}$ ABG 13 February 1786.

101 In the Birmingham advertisement Grimaldi calls himself "dentist to her Majesty, Prince of Wales, Princesses of Brunswick etc.", but he does not appear to feature in any official lists. (Cf. Dobson, op. cit., note 56 above). There is some confusion as to whether there is any connexion between Grimaldi the clown and the dentist of the same name.

${ }^{102}$ ABG 18 July 1785.

${ }_{103}$ Bath Chronicle 3 August 1780 (quoted by Campbell, op. cit., note 36 above, p. 195).

104 Martin Van Butchell 1735-1814 has been examined in some detail by Campbell (op cit., note 36 above, pp. 223-236). As a young man Van Butchell attended courses in anatomy and surgery given by the Hunters and was later to be associated with the younger brother. He appears to have 


\section{James Blair (1747-1817), provincial dentist}

tions cost the patient one guinea, artificial teeth 5 guineas each, natural teeth 10 guineas each, a lower set $£ 42$, an upper $£ 63$ and a complete set the phenomenal sum of $£ 105$, "the Money paid first". (As a point of comparison, exactly two hundred years later the fee received by a dentist from the National Health Service for a complete set is $\mathrm{f28}$.)

The orthodontic treatment which Blair offered in the 1790 s was in no way exceptional. There were frequent advertisements in the press from practitioners such as Grimaldi who "sets Children's Teeth to right, and gives them Uniformity", 146 and George Bott junior who claims that "he perfectly understands the removing of Children's Teeth, which, if neglected, are very apt, from the Age of six to fifteen, to grow out of their proper Places". ${ }^{165}$ The techniques and principles are also discussed in some detail by the writers of the day. Berdmore points out that the permanent teeth may be forced into an abnormal position leading to a double row "if they [the milk teeth] are permitted to remain too long". ${ }^{168}$ However, although Blair was evidently following the same principles as Berdmore, Wooffendale, and Hunter, none of his advertisements uses direct quotations from their works. The closest parallel to be found is with Hunter's expression "the appearance of a double row". 167

It is not yet possible to make any valid comparisons between Blair and his contemporary dental practitioners with regard to his itinerant habits. Whilst it is well known that eighteenth- and nineteenth-century dentists travelled around the country, and it is scarcely possible to examine a contemporary newspaper without encountering their advertisements, there have been no other detailed studies of the movements of individual provincial dentists. Wherever Blair went he crossed the paths of fellowmembers of the fraternity of advertising dentists. (Pasco Aranson, for instance, practised in many of the same places as Blair-Cambridge, Chester, Liverpool, and Shrewsbury.) Only further studies will reveal just how large this fraternity was, whether they divided up the country into circuits, and how much of the year they normally spent on the road. Certainly, in Blair's case, "itinerant" does not mean "of no fixed abode", and his movements are not to be compared with those of the travelling actor.

The apparent increase in the number of dentists in the last two decades of the eighteenth century coincides with vast improvements in the condition of the roads and in the coaches which travelled on them. One wonders whether this was the opportunity frustrated dentists had been waiting for to extend their practices, or whether improved facilities attracted restless, rootless showmen who took up dentistry to justify their own inclinations. It is of some interest that quite a number of dentists (for example Grimaldi, Armand Talma, Charles Bew, Hayden Coffin, and Blair himself) had previous connexions with the stage, either as actors or as members of

taken up dentistry in the mid-1760s. An eccentric of the highest order, he was notorious for his extraordinary clothes and habits. He assisted William Hunter and William Cruikshank to embalm the body of the first Mrs. Van Butchell, which he then kept in a case with a glass lid and exhibited to the public. His later activities extended far beyond the bounds of dentistry and he acquired a reputation for his cure for fistulae.

168 ABG 3 January 1791.

166 Berdmore, op. cit., note 43 above, p. $201 \mathrm{ff}$.

167 Hunter (1778), op. cit., note 153 above, p. 115. 


\section{Christine Hillam}

theatrical families. It is almost as though they had acquired the travelling habit and found it difficult to rid themselves of it. ${ }^{168}$

It would be equally dangerous to attempt too firm an assessment of Blair's character, bearing in mind the nature of the sources available. He can be seen as enterprising or merely opportunist; realistic or restless; an observant clinician or an astute imitator and advertiser. Did modesty and a sense of professional ethics restrain him from producing an advertising treatise of his own, or had he simply never formulated any ideas on the subject? His advertisements betray none of the eccentricity of a dentist visiting the same towns year after year in the face of ridicule and an absence of patients, and consequently one can assume that he was a successful practitioner. He does not fall into the category of the itinerant quack and toothpuller who visited a town only once, leaving before the disastrous results of his "operations" had become evident.

Blair's advertised treatments became less fanciful over the years and for the second half of his career as a dentist he appears to have had so established a clientele that he felt no need to enumerate them. The overall picture is of an unexceptional practitioner who, whilst not necessarily contributing anything revolutionary to the development of his profession, offered the best of contemporary treatment and won for himself a respected position in the society in which he lived.

\section{SUMMARY}

An account is given of the life of James Blair (1747-1817), tracing his progression from barber, wigmaker, perfumer, and toyman to dentist. His stays in Leicester (1769-1800), Chester (1800-1807), and Liverpool (1807-1817) are examined in detail, as are his travels as an itinerant practitioner in central and north-west England between the early 1790 s and 1817 . An attempt is made to consider Blair in relation to his fellow dentists and to the most eminent dental writers of the day. Mention is also made of his descendants in the medical and dental professions. The prime sources of information are Blair's own newspaper advertisements.

\section{ACKNOWLEDGEMENTS}

I am, as ever, deeply indebted to R. A. Cohen, F.F.D., L.D.S. (Part-time Senior Research Fellow in the History of Dentistry, University of Birmingham) for his scholarly advice and for access to his private collection of dental texts and prints. Special thanks are due to Mrs. P. Molyneux for permission to reproduce the miniature portrait of James Blair and to the Editor of the British Dental Journal for the use of the photographic plate made when this illustration appeared in the Journal. I am most grateful to the staff of the following record offices and libraries: Barnes Medical Library (University of Birmingham); Blairgowrie; Library of the British Dental Association; Cambridge; Chester; Edinburgh; Leicester; Liverpool: Manchester; Shrewsbury; Stafford; Salt Library, Stafford. Thanks are also due to the Editor of the Chester Chronicle for access to the newspaper's files, to the Curator of the Museum at Liverpool Dental School, and to D. G. Hillam for much of the information on George Bott. The support of the Wellcome Trustees is gratefully acknowledped.

108 I am indebted to R. A. Cohen for bringing this phenomenon to my attention. 